\title{
Direct Evidence for Geophyte Exploitation in the Wyoming Basin
}

\author{
Kaley Joyce, Lisbeth A. Louderback (D, and Erick Robinson
}

\begin{abstract}
In the Wyoming Basin, archaeological sites dating from the Early Archaic to Late Prehistoric are often found associated with or adjacent to dense populations of Cymopterus bulbosus (springparsley), a nutritious geophyte that would have been an important food source for prehistoric humans living in the region. Experimental data have shown that the caloric return rates of $\mathrm{C}$. bulbosus were enough to support seasonal exploitation by foragers, yet there has been no direct evidence for the use of this geophyte from the archaeological record. In this study, we examine starch granules from 10 ground stone tools excavated from two stratified, multicomponent archaeological sites in the Wyoming Basin to determine if $\mathrm{C}$. bulbosus was collected and consumed in the past. Taproots of $\mathrm{C}$. bulbosus were collected from two populations in the immediate vicinity of the archaeological sites in order to develop a modern starch reference. Identification of Cymopterus starch granules is based on a systematic study of those reference granules. The presence of Cymopterus starch on the ground stone artifacts suggests that prehistoric foragers were collecting and consuming these geophytes. These findings support previous hypotheses about geophyte use in southern Wyoming and therefore have implications for increasing human populations as well as settlement and subsistence decisions.
\end{abstract}

Keywords: Cymopterus bulbosus, starch granule analysis, Holocene hunter-gatherers, western North America

En la Cuenca de Wyoming, sitios arqueológicos de la época Temprana del Arcaico al periodo Prehistórico tardío han sido asociados con/o contiguos con poblaciones densas de Cymopterus bulbosus (perejil de primavera), un geófito nutritivo que hubiera sido un recurso alimenticio importante para los humanos prehistóricos que habitaron la región. Data experimental ha demostrado que los retornos calóricos de C. bulbosus eran suficiente para soportar la utilización por temporadas de los recolectores, no obstante, el record arqueológico no ha proporcionado evidencia directa del uso de este geófito. En este estudio, examinamos residuos de almidón localizados en diez herramientas de moler excavadas de dos sitios arqueológicos, estratificados y multi-componente, en la Cuenca de Wyoming para determinar si C. bulbosus fue recolectada y consumida en el pasado. Raíces principales de C. bulbosus fueron recolectadas de dos poblaciones vecinas de los sitios arqueológicos para desarrollar una referencia moderna del almidón. La identificación de los residuos de almidón de Cymopterus es basada en un estudio sistemático de los residuos referentes. La presencia de residuos de almidón de Cymopterus en los artefactos de moler sugiere que los recolectores prehistóricos recolectaban y consumían estos geófitos. Estos resultados apoyan hipótesis previas sobre el uso de geófitos en el sur de Wyoming y, por lo tanto, tienen implicaciones sobre el aumento de poblaciones humanas y decisiones sobre asentamiento y subsistencia.

Palabras clave: Cymopterus bulbosus, análisis de residuos de almidón, cazadores-recolectores del Holoceno, noroeste de América del Norte

$\mathrm{E}$ xploitation of geophytes (perennial plants that store edible starch in underground storage organs, or "USOs") has been

well documented in the ethnographic literature in western North America. During their 18041806 expedition along the Missouri and

Kaley Joyce and Lisbeth A. Louderback (llouderback@ anthro.utah.edu, corresponding author) — Natural History Museum of Utah, Department of Anthropology, University of Utah, Salt Lake City, UT, USA

Erick Robinson — Department of Anthropology, Boise State University, Boise, ID, USA

American Antiquity 87(2), 2022, pp. 236-247

Copyright (C) The Author(s), 2021. Published by Cambridge University Press on behalf of the Society for American Archaeology. This is an Open Access article, distributed under the terms of the Creative Commons Attribution licence (https://creativecommons.org/licenses/by/4.0/), which permits unrestricted re-use, distribution, and reproduction in any medium, provided the original work is properly cited.

doi:10.1017/aaq.2021.115 
Columbia Rivers and across the Rockies, Lewis and colleagues (1814) noted roots and tubers from several different plant taxa-such as cattails (Typha), rush (Carex), wapato (Sagittaria), and thistle (Cirsium) — that were commonly collected and consumed by the Northwest and Plains Indian tribes as well as the Northern Shoshone in southern Idaho. Geophytes commonly consumed by Native American tribes of the Great Basin (e.g., Northern Paiute, Southern Paiute, Ute, Shoshone, Goshute) include the taproots or rootstocks of biscuitroot (Lomatium), yampah (Perideridia), bitterroot (Lewisia), springparsley (Cymopterus); bulbs of fritillary (Fritillaria), wild onion (Allium), sego lily (Calochortus); and corms of Brodiaea-type geophytes (Dichelostemma; Chamberlin 1909, 1911; Couture et al. 1986; Kelly 1932, 1934; Lawton et al. 1976; Steward 1933). Several tribes in the American Southwest (e.g., Apache, Navajo, Hopi, Pueblo, Zuni) also collected geophytes, including rootstocks of springparsley, tubers of wild potato (Solanum jamesii), horsenettle (Solanum fendleri), and bulbs of sego lily and wild onion (Castetter 1935; Castetter and Opler 1936; Fewkes 1896; Swank 1932; Vestal 1940, 1952).

Geophytes are known to be a highly valued food item, but they also have socioecological implications for human societies across the globe (Fulkerson and Tushingham 2021; O'Connell et al. 1999). Archaeologists working in southern Wyoming hypothesize that these predictable and nutritious plant resources encouraged a stable, long-term pattern of land use that ultimately resulted in sustaining prehistoric human populations throughout the Holocene (Larson 1997; Smith 2003; Smith and McNees 2011). Although return rates for geophytes in western North America vary widely, some (e.g., Lomatium) have a ranking similar to avian and small mammal resources, and their encounter rates are less variable than those of large, mobile prey (Couture et al. 1986; Smith and McNees 2005; Zeanah 2004; Figure 1). Unfortunately, there is difficulty in finding archaeological evidence of geophyte use because the fleshy underground storage organs do not preserve well compared to other plant parts that are hard and dense and/or charred (Lepofsky and Peacock 2004). Most archaeologists, therefore, rely on indirect evidence such as pits, slab-lined hearths, flake tool morphology, digging sticks, or digging stick weights to infer consumption (Bradley et al. 2020; Dering 1999; Eerkens and Rosenthal 2002; Lepofsky and Peacock 2004; McGuire and Stevens 2016; Pool 2001; Sutton 2014; Thoms et al. 2018). Although digging sticks are suggestive, they often do not preserve well, and their size and shape do not indicate which plant species were being utilized. Likewise, if flake tools are used to infer the manufacture of digging sticks, then this becomes indirect evidence of indirect evidence.

Burned remains of geophytes provide direct evidence of use and have been found in archaeological contexts (Dering 1999; Gill 2016; Gill et al. 2021; Lyons and Ritchie 2017; Thoms 1989). Starch granule analysis also provides direct evidence of geophyte use and may allow identification — sometimes down to species level —of plants processed on or cooked in implements, such as baskets, ground stone, or pottery (e.g., Herzog and Lawlor 2016; Rankin 2016; Rhode and Rankin 2020; Louderback and Pavlik 2017). Even though ethnographic evidence suggests that geophytes were an important food source to Native peoples living in southern Wyoming (Steward 1933), there is virtually no support in the archaeological record. However, there appears to have been processing of Lomatium and Lewisia at High Rise Village in high elevations of the Wind River Range, Wyoming (Rankin 2016).

A common geophyte species found near and within archaeological sites in southern Wyoming is Cymopterus bulbosus A. Nelson (bulbous springparsley). Its starchy taproot (Figure 2) could have been an important food source for prehistoric humans living in the region. For example, traditional processing methods suggest that $C$. bulbosus was eaten raw after bark was peeled from the taproot, or roasted in ashes, cooked in milk, or dried and ground for overwintering (Castetter 1935; Vestal 1952). Furthermore, experimental data show that the caloric return rates of $C$. bulbosus were enough to support seasonal exploitation by foragers (Smith and McNees 2005). Yet, there has been no direct evidence for the use of this geophyte from the archaeological record.

In this study, starch granule analysis on ground stone tool collections from older sites 


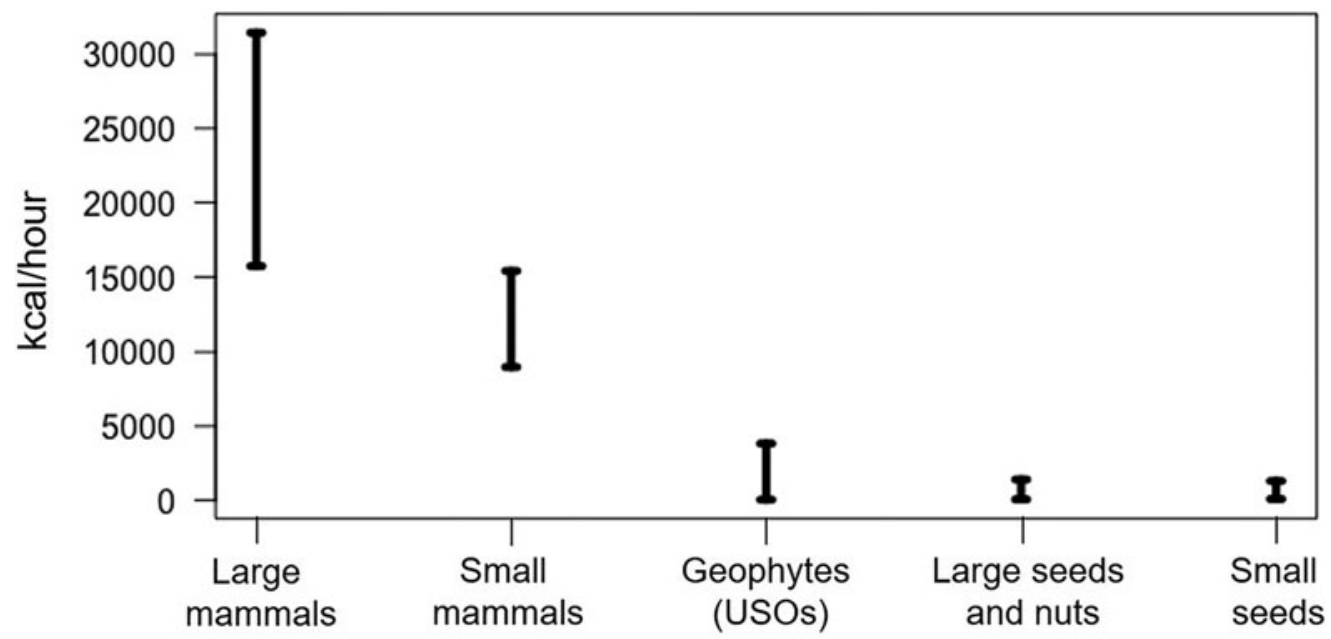

Figure 1. Post-encounter return rates (kcal/hour) for dietary resources common across western North America. Return rate values are compiled from the published literature (e.g., Broughton et al. 2011; Couture et al. 1986; Diehl and Waters 2006; Gremillion 2004; Kelly 1995; Rhode and Rhode 2015; Simms 1987; Smith and McNees 2005; Smith et al. 2001; Ugan and Rosenthal 2016).

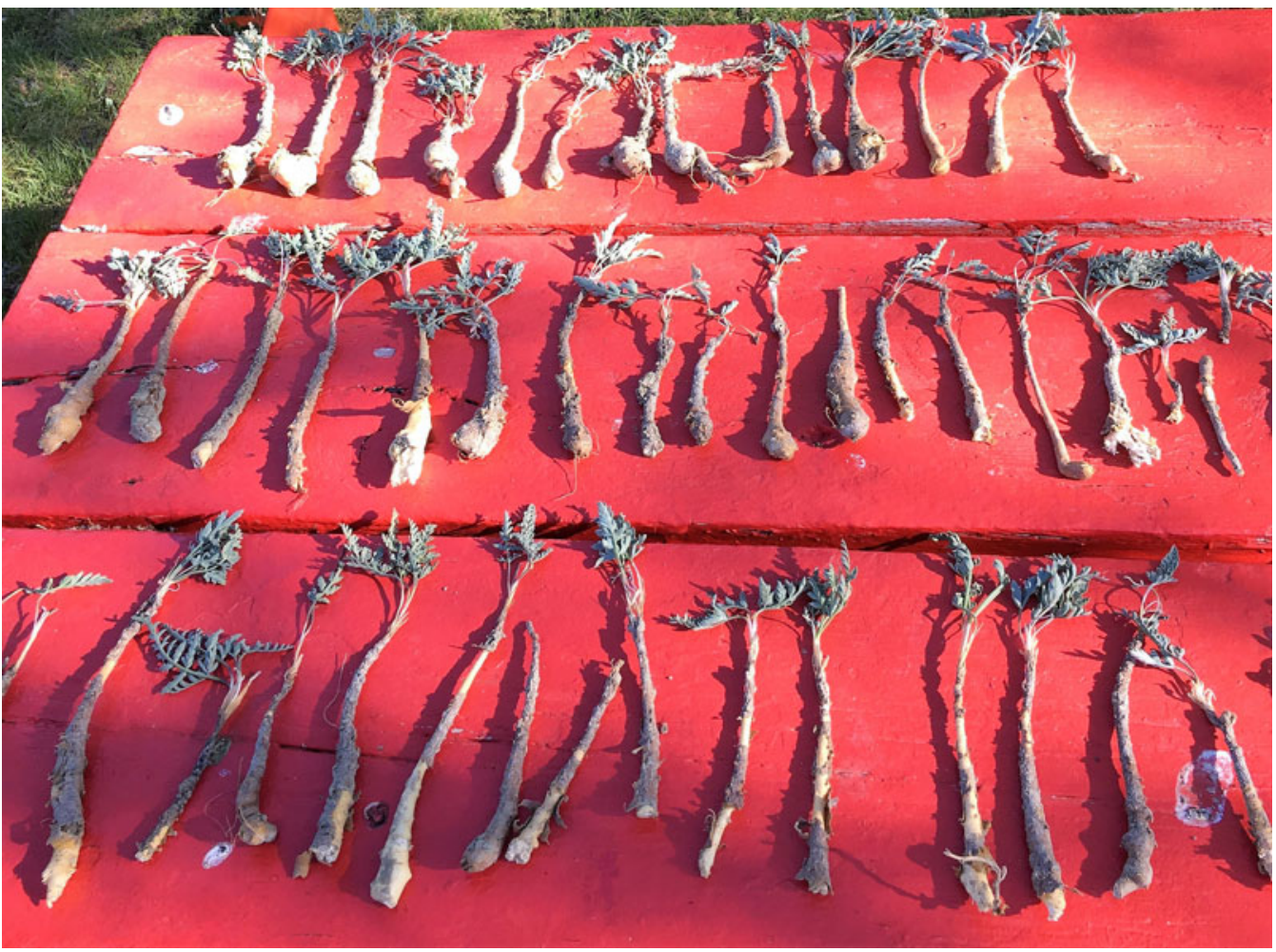

Figure 2. Cymopterus bulbosus with starchy taproots. Plants were collected in June 2017 from patches adjacent to sites 48 UT375 and $48 S W 8842$ in the Wyoming Basin (photograph courtesy of Erick Robinson). (Color online) 


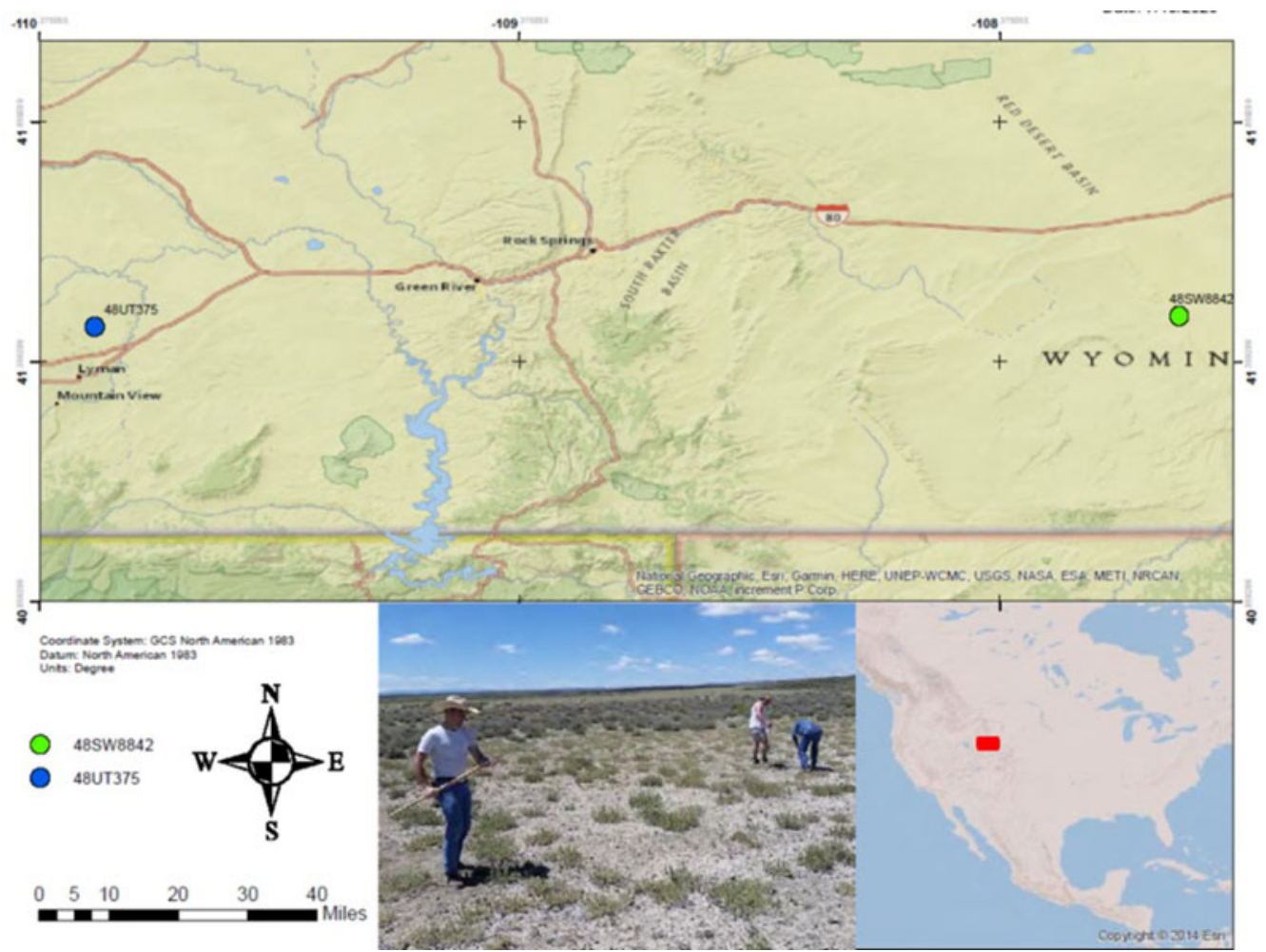

Figure 3. Location of sites $48 \mathrm{UT375}$ and $48 \mathrm{SW8842}$ in Green Basin, Wyoming. Cymopterus bulbosus populations were located in the immediate vicinity $(<200 \mathrm{~m})$ of the sites. Bottom-middle photo shows field crew collecting $C$. bulbosus at Population 1, near site 48 UT375 (photograph courtesy of Bruce Pavlik). (Color online)

located in lowland settings was conducted to provide further evidence for geophyte exploitation in southern Wyoming. Focusing specifically on $C$. bulbosus, we systematically measured granules from modern reference specimens to aid in the identification of archaeological granules. Starch granules were extracted from 10 manos and metates found in two stratified, multicomponent archaeological sites48UT375 and 48SW8842 - in the Wyoming Basin to contribute to a more thorough understanding of resource consumption patterns throughout the Holocene in this region.

\section{Study Sites}

\section{Site $48 U T 375$}

Site 48UT375 is a multicomponent site situated on a low interfluvial ridge near the ephemeral drainage of Austin Wash, approximately $13 \mathrm{~km}$ northeast of Lyman in Uinta County, Wyoming
(Reust et al. 2002; Smith et al. 2003; Figure 3). Aeolian deposits up to $118 \mathrm{~cm}$ deep yielded four separate components: Late Paleoindian, Paleoindian / Early Archaic (Great Divide Phase), Middle Archaic (Pine Spring Phase), and Late Archaic / Late Prehistoric (Reust et al. 2002). The focus of this study will be on Components 1 (Late Paleoindian, 9400-9600 cal BP) and 3 (Middle Archaic, 4400-4900 cal BP) because they are the two components that yielded ground stone tools. Geophyte consumption was suggested at site 48UT375 due to the presence of ground stone tools, the abundance of firecracked rock, and the dense patches of geophytes surrounding the site, although no direct evidence was recorded at the time (Smith et al. 2003).

\section{Site 48 SW8842}

Site 48SW8842 is a deeply stratified site situated in sand shadow deposits in the lee of a sandstone ridge overlooking a playa flat that is a tributary of 
North Barrel Springs Draw, approximately 24 $\mathrm{km}$ south of Wamsutter in Sweetwater County, Wyoming (Pool 2001; Figure 3). Five stratified cultural levels were excavated, defined as "analytical units": AU1 (Late Prehistoric Uinta Phase), AU2 (Late Archaic Pine Spring Phase), AU3 (Early Archaic Opal Phase), AU4 (Early Archaic Great Divide Phase), and AU5 (Paleoindian and transitional Paleoindian / Early Archaic Great Divide Phase). This study will focus on ground stone tools recovered form AU1, AU2, AU3, and AU4, ranging in age from approximately 1400 to $8300 \mathrm{cal} \mathrm{BP}$. It has been suggested that several of the slab-lined pits and hearths excavated from 48SW8842 were used for the preparation and baking of geophytes (Pool 2001).

\section{Material and Methods}

\section{Ground Stone Assemblage}

The ground stone collections from sites 48UT375 and 48SW8842 are accessioned at the University of Wyoming Archaeological Repository. Ten ground stone tools that span the Holocene in age (1400-9600 cal BP) were examined for starch granules. Ground stone artifacts from 48UT375 (three manos) were all manufactured from quartzite, whereas at $48 \mathrm{SW} 8842$ (one mano, six metates), were manufactured from sandstone. These artifacts were chosen because they occur in multiple levels spanning the Early Archaic to Late Prehistoric times, including a mano from 48UT375 that dates to around 9400-9600 cal BP. Full descriptions of the ground stone tools are in Reust and colleagues (2002) and Pool (2001), and images of the 10 tools examined in this study are in Supplemental Figure 1.

\section{Starch Extraction from Reference Materials}

Reference material for this study includes a total of six C. bulbosus plants collected from two populations $(n=3$ individuals from each population) in southwestern Wyoming (Figure 3). Population 1 is located approximately $170 \mathrm{~m}$ west and $150 \mathrm{~m}$ north of site 48UT375, and Population 2 is situated about $170 \mathrm{~m}$ west and north of site 48SW8842. Cymopterus bulbosus specimens that were collected in the field were brought to the Natural History Museum of Utah
(NHMU) Archaeobotany Lab for sample preparation and processing. Cortex and stele of the taproots were isolated and ground with a small amount of 50/50 glycerol and $\mathrm{DH}_{2} \mathrm{O}$ solution in a sterile tissue homogenizer and mounted onto glass slides.

\section{Starch Extraction from Ground Stone Artifacts}

A portion of the worked surface from each ground stone artifact was sonicated for three minutes in a sterile weigh boat with a small amount of deionized $\left(\mathrm{DH}_{2} \mathrm{O}\right)$ water. The samples were then sieved through a $125 \mu \mathrm{m}$ mesh Endecott sieve to remove material greater than $125 \mu \mathrm{m}$. The samples $(<125 \mu \mathrm{m})$ were then transferred to a $50 \mathrm{~mL}$ tube and centrifuged for 5 minutes at 3,000 RPM, and the supernatant was discarded. The pellets were resuspended and transferred to $15 \mathrm{~mL}$ tubes and centrifuged for 5 minutes at 3,000 RPM, and the supernatant was decanted. Heavy liquid was used to isolate starch granules from the samples; $5 \mathrm{~mL}$ of lithium heteropolytungstate (LST, specific gravity 2.00 ) was added to each sample and resuspended with a vortex mixer. The samples were set aside for 20 minutes to allow starch granules and other organics to float to the top. The top layer of organics was then removed with a pipette and placed in new $15 \mathrm{~mL}$ tube. Samples were rinsed twice with $10 \mathrm{~mL}$ of $\mathrm{DH}_{2} \mathrm{O}$ and centrifuged for 3 minutes at 3,000 RPM in order to remove any residual heavy liquid. A final rinse was performed with $7 \mathrm{~mL}$ of acetone and centrifuged for 5 minutes at 3,000 RPM. The supernatant was decanted, and the pellets were left to dry overnight. The pellets were mixed with a small amount of 50/50 glycerol and $\mathrm{DH}_{2} \mathrm{O}$ solution and mounted on glass slides.

\section{Microscopy}

Each slide was scanned using a transmitted brightfield microscope fitted with polarizing filters and Nomarski optics (Zeiss Axioskop 2, Zeiss International, Göttingen, Germany). A digital camera (Zeiss HRc) with imaging and measurement software (AxioVision) were used to capture images of and measure starch granules. For each reference sample, randomly generated $X$ and $Y$ coordinates on the microscope stage were used to measure and photograph 
approximately 100 granules from each individual plant ( $n=\sim 300$ from each population). All starch granules present in these photographs were measured and examined for morphological features. Photograph locations were distant enough from one another to ensure that starch granules were not photographed twice.

To examine surface features and threedimensional shapes of starch granules, scanning electron microscopy (SEM) was also used. A small portion of each processed sample was mounted directly onto aluminum stubs using double-sided carbon tape. An FEI Quanta 600F SEM (FEI Company, Hillsboro, Oregon, USA) with a high-resolution field-emission source was used to image starch granules.

\section{Granule Size and Morphology}

The size of each starch granule was measured as the maximum length through the hilum. Granules were also examined for the presence of morphological features including lamellae, hilum position, angular margins, fissures at the hilum, pressure facets, and depressions along the margins (International Code for Starch Nomenclature [ICSN] 2011; Reichert 1913). Starch granule size tends to be non-normally distributed and, therefore, relying on mean granule size is not appropriate for identification purposes (Louderback et al. 2017). To assess the normality of granule size distributions, the Shapiro-Wilk test was employed and reported as $p$-values using the $\mathrm{R}$ statistical environment ( $\mathrm{R}$ Core Team 2019). $P$-values less than 0.05 indicate that the distributions deviate significantly from normal.

Applying a statistical analysis to starch granule identification promotes reproducibility and an overall increase in confidence (Gao et al. 2021; Louderback et al. 2017). It is becoming standard practice to measure the size, shape, and morphological features of reference starch granules from multiple populations so that variation and statistical significance can be assessed (see Brown and Louderback 2020; Liu et al. 2014; Wilks et al. 2021).

\section{Results \\ Reference Material \\ Granule Size. Starch granule lengths were not normally distributed in all reference}

specimens except for individual B $(p=0.4)$. Therefore, all measurements have been log transformed for calculation of descriptive statistics (Table 1). Starch granule measurements from individual plants were then pooled for overall size range and morphological analyses. Smaller granules generally exhibit fewer diagnostic features (Louderback et al. 2017), so the top $20 \%$ fraction was used for taxonomic identification. Although granule length was slightly different between the two populations, it is not statistically significant $(t(4)=0.611$, $p=0.57)$.

Granule Morphology. Morphological features including hilum position, lamellae, granule shape, fissures, pressure facets, and depressions were recorded for each granule (Figure 4). Although these features have long been known and previously described (ICSN 2011; Reichert 1913), some had to be refined for the present study. For example, pressure facets are large, obvious indentations that develop in compound granules common to Poaceae, Apiaceae, and other plant families (Figures $4 \mathrm{~b}$ and $4 \mathrm{e}$ ). Depressions ("pits"), however, are small, subtle indentations that may or may not be the result of compound granule formation (ICSN 2011; Figures $4 \mathrm{c}$ and $4 \mathrm{f}$ ). When viewed in transmitted light (two dimensions), depressions on spherical granules (e.g., Cymopterus) can only be seen when positioned along the outer margin. But on the surface of flattened, lenticular granules (e.g., Triticeae grasses, such as Leymus, Hordeum) they are readily observed (Brown and Louderback 2020; Perry and Quigg 2011).

Fissures at the hilum (Figure 4d) are also commonly observed in many plant families and often used to identify archaeological maize granules (e.g., transverse, stellate, radial fissures; Holst et al. 2007; Musaubach et al. 2013; Wilks et al. 2021). They are also common in Apiaceae, but not necessarily diagnostic at the level of genus. Fissures and pressure facets have been readily observed on Apiaceae starch (e.g., Lomatium cous), but depressions along the margin of the granules seem unique to Cymopterus (bulbosus, in this study), thereby distinguishing it from species of Lomatium and other Apiaceae so far examined (Herzog 2014; Herzog and Lawlor 2016; Rankin 2016). 
Table 1. Descriptive Statistics and Shapiro-Wilk Normality Test of Starch Granule Lengths of Individual Plants (A, B, C, X, Y, Z) and Populations (1 and 2).

\begin{tabular}{|c|c|c|c|c|c|c|c|c|}
\hline \multirow[b]{2}{*}{ Population } & \multirow[b]{2}{*}{ Individual } & \multicolumn{7}{|c|}{ Starch Granules } \\
\hline & & $\begin{array}{l}\text { Sample Size } \\
(n)\end{array}$ & $\begin{array}{l}\text { Mean Length } \\
\quad(\mu \mathrm{m})\end{array}$ & $\begin{array}{c}\text { Standard } \\
\text { Deviation } \\
\quad(\mu \mathrm{m})\end{array}$ & $\begin{array}{l}\text { Median } \\
(\mu \mathrm{m})\end{array}$ & Skewness & Kurtosis & Shapiro-Wilk \\
\hline \multirow[t]{3}{*}{ Population 1} & A & 100 & 12.23 & 1.36 & 11.53 & 0.15 & -0.10 & $p<0.0003$ \\
\hline & B & 100 & 17.70 & 1.37 & 18.52 & -0.44 & -0.10 & $p=0.4$ \\
\hline & $\mathrm{C}$ & 100 & 7.39 & 1.52 & 6.90 & 0.39 & -0.37 & $p<0.0005$ \\
\hline \multirow[t]{3}{*}{ Population 2} & $\mathrm{X}$ & 100 & 12.48 & 1.39 & 12.45 & 0.67 & 1.56 & $p<0.0006$ \\
\hline & $\mathrm{Y}$ & 100 & 5.97 & 1.53 & 5.77 & 0.60 & 0.19 & $p<0.0007$ \\
\hline & $\mathrm{Z}$ & 100 & 12.17 & 1.48 & 12.14 & -0.26 & 0.70 & $p<0.0008$ \\
\hline Population 1 & $\mathrm{~A}, \mathrm{~B}, \mathrm{C}$ & 3 & 12.44 & 5.16 & 12.23 & & & \\
\hline Population 2 & $X, Y, Z$ & 3 & 10.20 & 3.67 & 12.17 & & & \\
\hline
\end{tabular}

Note: All measurements have been log transformed except for Population 1B, which was normally distributed.

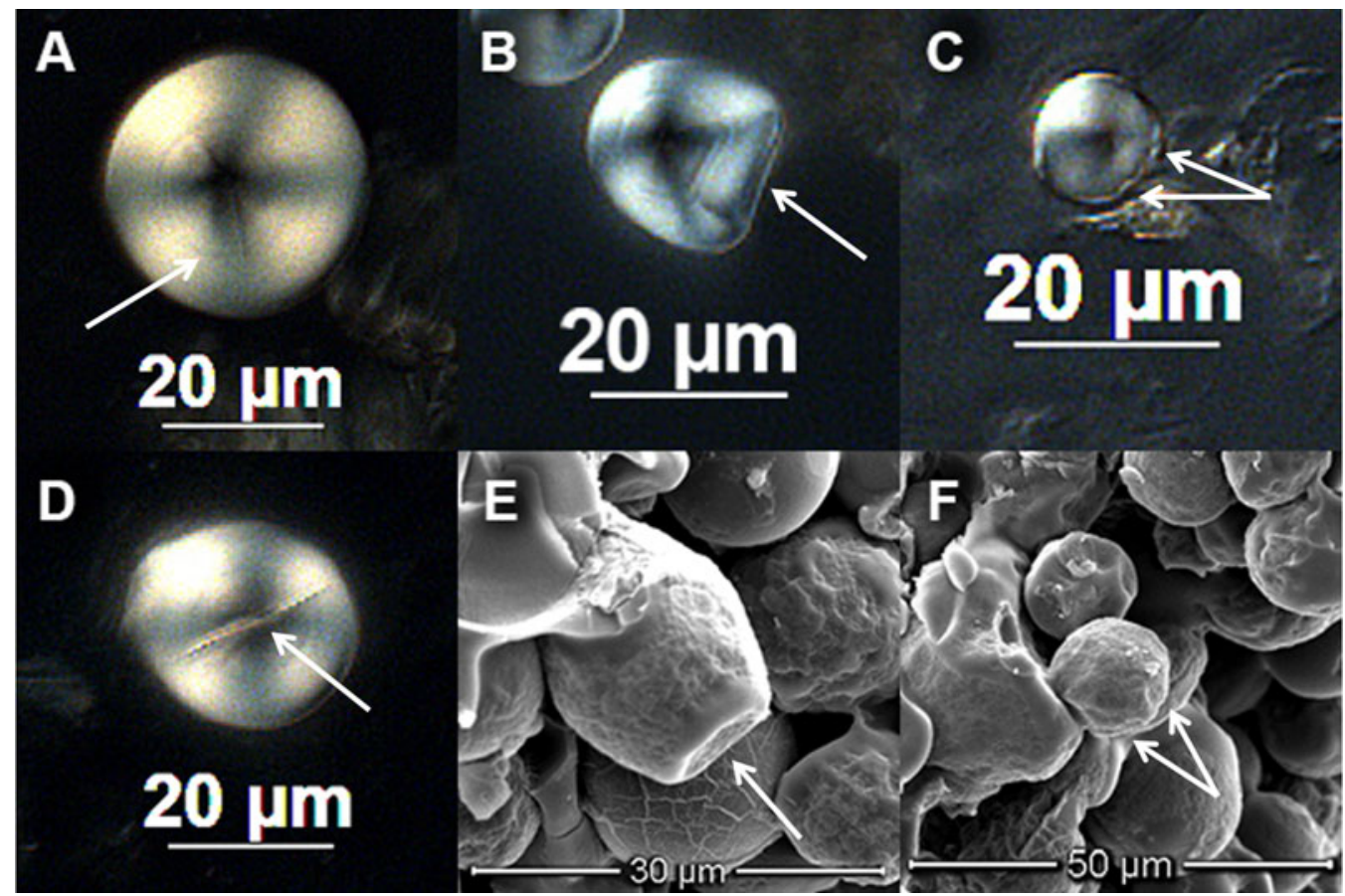

Figure 4. Morphological features of $C$. bulbosus. Images from $C$. bulbosus reference granules taken under transmitted light (differential interference contrast; DIC) and scanning electron microscope (SEM): (A) lamellae (Population 1B, DIC), (B) pressure facet (Population 2Z, DIC), (C) depressions (Population 1B, DIC), (D) fissures at the hilum (Population 1B, DIC), (E) pressure facet (SEM), (F) depressions (SEM). SEM images are from a $C$. bulbosus specimen from the Garrett Herbarium (NHMU). (Color online)

Population 1. Features common for the modern reference samples collected from Population 1 include distinct lamellae (frequency $[\mathrm{f}]=$ $0.65)$, pressure facets $(f=0.25)$, depressions $(f=0.52)$, fissures occurring at the hilum $(f=$
0.77). The most common shape for the granules is round ( $f=0.67$ ), with few that are oval $(f=$ $0.23)$ and bell shaped $(f=0.10)$. No angular shapes were recorded. Centric hila are the most prevalent $(f=0.70)$, with few that are slightly 
Table 2. Population, Frequencies of Morphological Features, and Size Range of the Upper $20 \%$ of Reference Starch Granules from the Two C. bulbosus Populations.

\begin{tabular}{|c|c|c|c|c|c|c|c|}
\hline Population & $\begin{array}{l}\text { Distinct } \\
\text { Lamellae }\end{array}$ & $\begin{array}{l}\text { Pressure } \\
\text { Facets }\end{array}$ & Depressions & $\begin{array}{l}\text { Fissures } \\
\text { at Hilum }\end{array}$ & Shape & Hilum & $\begin{array}{l}\text { Size Range } \\
\quad(\mu \mathrm{m})\end{array}$ \\
\hline $\begin{array}{l}\text { Population } 1 \\
\quad(n=60)\end{array}$ & 0.65 & 0.25 & 0.52 & 0.77 & $\begin{array}{l}\text { Round: } 0.67 \\
\text { Oval: } 0.23 \\
\text { Bell: } 0.10 \\
\text { Angular: } 0.00\end{array}$ & $\begin{array}{l}\text { Centric: } 0.70 \\
\text { Slightly Eccentric: } 0.18 \\
\text { Eccentric: } 0.12\end{array}$ & $18.73-33.64$ \\
\hline $\begin{array}{l}\text { Population } 2 \\
\quad(n=60)\end{array}$ & 0.70 & 0.37 & 0.52 & 0.50 & $\begin{array}{l}\text { Round: } 0.63 \\
\text { Oval: } 0.18 \\
\text { Bell: } 0.18 \\
\text { Angular: } 0.00\end{array}$ & $\begin{array}{l}\text { Centric: } 0.70 \\
\text { Slightly Eccentric: } 0.22 \\
\text { Eccentric: } 0.08\end{array}$ & $14.24-38.64$ \\
\hline
\end{tabular}

eccentric $(f=0.18)$ and eccentric $(f=0.12)$. The size range for the upper $20 \%$ of granules is 18.73-33.64 $\mu \mathrm{m}$ (Figure 4, Table 2).

Population 2. Population 2 feature frequencies were similar to Population 1. All diagnostic features were the same, with some variation in frequency. Population 2 granules exhibited distinct lamellae $(f=0.70)$, pressure facets $(f=0.37)$, depressions $(f=0.53)$, and fissures at the hilum $(f=0.50)$. Round shapes are most common $(f=0.67)$, with a smaller percentage of oval $(f=0.18)$ and bell shapes $(f=0.18)$. No angular shapes were documented. Centric hila are observed the most $(f=0.70)$, with fewer slightly eccentric $(f=0.22)$ and eccentric $(f=0.08)$. The size range for the upper $20 \%$ of granules is $14.24-38.64 \mu \mathrm{m}$ (Figure 4, Table 2).

Table 3. Summary of Starch Granules Extracted from Ground Stone Tools Excavated at Sites 48 UT375 and 48 SW8842.

\begin{tabular}{|c|c|c|c|c|c|c|c|c|c|}
\hline \multirow[b]{2}{*}{$\begin{array}{l}\text { Site } \\
\text { Number }\end{array}$} & \multirow[b]{2}{*}{ Provenience } & \multirow[b]{2}{*}{$\begin{array}{c}\text { Radiocarbon } \\
\text { Age (BP) }\end{array}$} & \multirow[b]{2}{*}{$\begin{array}{c}\text { Calibrated } \\
\text { Age (cal } \\
\text { BP })^{\mathrm{a}}\end{array}$} & \multirow[b]{2}{*}{ FS\# } & \multirow[b]{2}{*}{ LS\# } & \multirow[b]{2}{*}{$\begin{array}{l}\text { Ground } \\
\text { Stone } \\
\text { Tool }\end{array}$} & \multirow[b]{2}{*}{$\begin{array}{c}\text { Total } \\
\text { Starch } \\
\text { Granules }\end{array}$} & \multicolumn{2}{|c|}{ Taxonomic Assignment } \\
\hline & & & & & & & & $\begin{array}{c}\text { Likely } \\
\text { Cymopterus } \\
\text { (or Other } \\
\text { Apiaceae) }\end{array}$ & $\begin{array}{l}\text { Definitively } \\
\text { Cymopterus }\end{array}$ \\
\hline 48UT375 & Component 1 & $\begin{array}{c}8330 \pm 40 \\
8450 \pm 40 \\
8470 \pm 40 \\
8490 \pm 40 \\
8640 \pm 40\end{array}$ & $9599-9376$ & 418 & 2 & mano & 47 & 1 & 一 \\
\hline 48UT375 & Component 3 & $\begin{array}{c}4030 \pm 70 \\
4040 \pm 40 \\
4220 \pm 40\end{array}$ & $4849-4370$ & 408 & 1 & mano & 50 & 1 & - \\
\hline 48UT375 & Component 3 & $\begin{array}{c}4030 \pm 70 \\
4040 \pm 40 \\
4220 \pm 40\end{array}$ & $4849-4370$ & 612 & 3 & mano & 72 & 2 & 一 \\
\hline 48SW8842 & AU1 & $1730 \pm 100$ & $1870-1413$ & 1934 & 8 & mano & 197 & 19 & 3 \\
\hline 48SW8842 & AU2 & $2950 \pm 100$ & $3364-2863$ & 239 & 4 & metate & 7 & 1 & - \\
\hline 48SW8842 & AU2 & $2950 \pm 100$ & $3364-2863$ & 253 & 10 & metate & 20 & 3 & - \\
\hline 48SW8842 & AU3 & $5150 \pm 70$ & $6176-5723$ & 1704 & 5 & metate & 18 & 1 & - \\
\hline 48SW8842 & AU3 & $5150 \pm 70$ & $6176-5723$ & 960 & 7 & metate & 14 & - & - \\
\hline 48SW8842 & AU4 & $7190 \pm 100$ & $8275-7795$ & 1751 & 6 & metate & 9 & 1 & - \\
\hline 48SW8842 & AU4 & $7190 \pm 100$ & $8275-7795$ & 895 & 9 & metate & 27 & 2 & - \\
\hline & & & & & & Totals & 461 & 31 & 3 \\
\hline
\end{tabular}

Note: Definitive assignment of three granules to Cymopterus based on the possession of four diagnostic characteristics. Another 123 granules were likely or possibly Cymopterus or other Apiaceae based on possession of fewer characteristics.

${ }^{a}$ Ages were calibrated using IntCal (Reimer et al. 2013). A Bayesian model was used to obtain $95 \%$ ranges. 


\section{Ground Stone Artifacts}

The tools from $48 \mathrm{UT} 375$ yielded 169 granules, and tools from 48SW8842 yielded 292 granules, for a total of 461 granules (Table 3). Nine out of the 10 tools produced granules assigned to Cymopterus. Using the morphological characteristics (i.e., lamellae, pressure facets, fissures, and depressions) defined by the reference granules, three archaeological granules were definitively assigned to Cymopterus, and 123 (for a total of 126) were likely or possibly Cymopterus or other Apiaceae based on possession of three or two characteristics (Figure 5, Supplemental Figure 2, Supplemental Table 1). Because we focused specifically on Cymopterus, the remaining 335 archaeological granules have yet to be identified. The three granules definitively assigned to Cymopterus (Figures $5 \mathrm{c}$ and $5 \mathrm{~d}$ ) were extracted from the same tool (SW8842-829; Figure 6), whereas the others came from the rest of the assemblage. Granule size for the 126 granules ranged from $8.48 \mu \mathrm{m}$ to $38.85 \mu \mathrm{m}$. Reduced confidence in identification was often due to the lack of depressions diagnostic of Cymopterus.

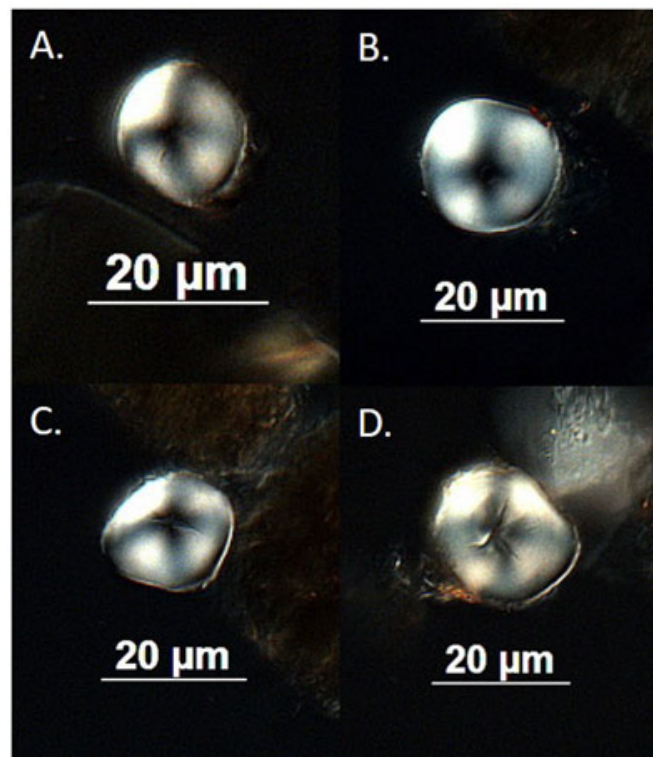

Figure 5. Archaeological granules extracted from SW8842-1934: (A) and (B) granules likely Cymopterus or other Apiaceae based on three diagnostic characteristics; (D) and (D) granules definitively assigned to Cymopterus based on four diagnostic characteristics. (Color online)
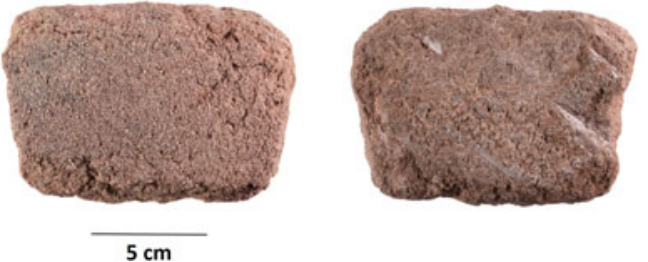

Figure 6. Sandstone mano (SW8842-1934) that yielded starch granules assigned to Cymopterus. (Color online)

\section{Discussion}

Our approach to identifying archaeological starch granules from ground stone artifacts (Louderback and Pavlik 2017; Louderback et al. 2017) began with a systematic study of $C$. bulbosus granules extracted from extant plant populations within the vicinity of sites $48 \mathrm{UT} 375$ and $48 \mathrm{SW} 8842$ in the Wyoming Basin. This allowed us to develop a set of statistically defined characteristics so that archaeological granules from many species could be sorted for purposes of identification. Using reference materials from two populations of C. bulbosus, those characteristics include hilum position, granule shape, distinct lamellae, fissures at the hilum, pressure facets, and depressions along the margin. All of these morphological features are commonly observed on Apiaceae granules, but only depressions along the margin were found to be a reliable feature of Cymopterus. Likewise, granule size was not an appropriate criterion for taxonomic identification because the upper $20 \%$ size range overlaps with several other plant taxa (e.g., Lomatium, Leymus, Quercus; Brown and Louderback 2020; Perry and Quigg 2011). Although it is highly probable that the granules observed on the ground stone tools are C. bulbosus, we took a more conservative approach by assigning taxonomy to archaeological granules at the genus (Cymopterus) or family (Apiaceae) levels.

A total of 461 granules were recovered from 10 ground stone tools, but less than $30 \%$ were assigned to Cymopterus or other Apiaceae. Nevertheless, these starch residues provide direct evidence that Cymopterus was collected, processed, and consumed and therefore support hypotheses about geophyte exploitation in the Wyoming Basin (Smith et al. 2003).

The availability of predictable food resources, such as Cymopterus, may have been among the 
ecological drivers for an observed increase in the number of housepits in Wyoming during the middle Holocene (Smith 2003; Smith and McNees 2011). This proliferation of housepit construction corresponds with a period of exponential population growth (8000-5500 cal BP) and increased spatial clustering of these foraging populations across the landscape (Robinson et al. 2019; Zahid et al. 2016). Seasonally predictable geophyte resources were likely a contributing factor in the persistent reoccupation of sites (Smith 2003; Smith and McNees 2011). The present study concludes that these foragers were collecting and processing geophytes, in particular Cymopterus, from dense patches adjacent to inhabited sites during a period of environmental change. Underground dormancy imparts a biological resistance to environmental change such that productive populations of this nutritious taproot would have been consistently available, even during the warm and dry middle Holocene (Eckerle and Taddie 2002; Smith and McNees 2005) offering high return rates and reliable yields.

Acknowledgments. Funding for this project was provided by the June Frison Memorial Fund of the George C. Frison Institute of Archaeology and Anthropology at the University of Wyoming. We thank the University of Wyoming Archaeological Repository (UWAR) for loaning the ground stone tool collections to the Natural History Museum of Utah (NHMU), where the starch analysis was conducted. Thanks to Michelle Knoll for photographing the ground stone tools. Many thanks to our field crew who helped collect several Cymopterus bulbosus plants: Carlton Gover, Ross Hillman, Jordan Jensen, and Bruce Pavlik. Thanks to Broadbent Land and Resources, GGR Management, and Sims Sheep Company for access to 48UT375; and to Diane Sapounakis for granting access to 48SW8842. We thank the Rawlins BLM field office for its support of our work at 48SW8842. The Garrett Herbarium at NHMU provided additional reference material for Cymopterus bulbosus. We are also grateful to Bruce Pavlik and members of the University of Utah Archaeological Center (UUAC) for providing feedback on earlier versions of this article. Thank you to three anonymous reviewers for thoughful comments and to Laura Perez for translating the abstract into Spanish.

Data Availability Statement. All data (starch granule measurements, descriptions, and images) are available on request. Please contact llouderback@anthro.utah.edu.

Supplemental Material. For supplemental material accompanying this article, visit https://doi.org/10.1017/aaq.2021.115.

Supplemental Figure 1. Ground stone tools from 48UT375 analyzed for starch: A) UT375-408; B) UT375-418; C) UT375612. Ground stone tools from 48 SW8842 analyzed for starch:
D) SW8842-239; E) SW8842-273; F) SW8842-895; G) SW8842-960; H) SW8842-1704; I) SW8842-1751; J) SW8842-1934.

Supplemental Figure 2. Images of archaeological granules assigned as likely or definitively belonging to Cymopterus. Granules 1-31 exhibit 3 diagnostic features (likely Cymopterus). Granules 32-34 exhibit 4 diagnostic features (definitively Cymopterus). Granules 1-4 are from site 48UT375 (granule 1 from FS418, 2 from FS408, and 3-4 from FS612). Granules 5-31 are from site 48SW8842 (granules 5-23 from FS 1934, 24 from FS239, 25-27 from FS253, 28 from FS1704, 29 from FS1751, 30-31 from FS895). All granules showing 4 diagnostic features (32-34) are from site 48SW8842 and FS1934

Supplemental Table 1. Inventory of starch granules from ground stone tools at sites 48UT375 and 48SW8842. Definitive taxonomic assignment of granules to Cymopterus is based on the possession of four diagnostic features. Granules that possessed three (likely Cymopterus) or two (possibly Cymopterus) features are also assigned

\section{References Cited}

Bradley, Erica J., Geoffrey M. Smith, and Teresa A. Wriston 2020 Possible Paleoindian Geophyte Use in Hawksy Valley, Oregon. Journal of California and Great Basin Anthropology 40:129-143.

Bronk Ramsey, Christopher

2009 Bayesian Analysis of Radiocarbon Dates. Radiocarbon 51:337-360.

Broughton, Jack M., Michael D. Cannon, Frank E. Bayham, and David A. Byers

2011 Prey Body Size and Ranking in Zooarchaeology: Theory, Empirical Evidence, and Applications from the Northern Great Basin. American Antiquity 76:403428.

Brown, Gloria H., and Lisbeth A. Louderback

2020 Identification of Starch Granules from Oak and Grass Species in the Central Coast of California. Journal of Archaeological Science: Reports 33:1-8. DOI:10. 1016/j.jasrep.2020.102549.

Castetter, Edward F.

1935 Ethnobiological Studies in the American Southwest I. Uncultivated Native Plants Used as Sources of Food. University of New Mexico Bulletin 4(1):1-44.

Castetter, Edward F., and Morris E. Opler

1936 Ethnobiological Studies in the American Southwest III: The Ethnobiology of the Chiricahua and Mescalero Apache. University of New Mexico Bulletin 4(5):1-63.

Chamberlin, Ralph V.

1909 Some Plant Names of the Ute Indians. American Anthropologist 11:27-40.

1911 The Ethno-Botany of the Gosiute Indians of Utah. Memoirs of the American Anthropological Association. New Era Printing Company, Lancaster, Pennsylvania.

Couture, Marilyn D., Mary F. Ricks, and Lucile Housley

1986 Foraging Behavior of a Contemporary Northern Great Basin Population. Journal of California and Great Basin Anthropology 8:150-160.

Dering, Phil

1999 Earth-Oven Plant Processing in Archaic Period Economies: An Example from a Semi-Arid Savannah in South-Central North America. American Antiquity 64:659-674. 
Diehl, Michael W., and Jennifer A. Waters

2006 Aspects of Optimization and Risk during the Early Agricultural Period in Southeastern Arizona. In Behavioral Ecology and the Transition to Agriculture, edited by Douglas J. Kennett and Bruce Winterhalder, pp. 63-86. University of California Press, Berkeley.

Eckerle, William P., and Sasha Taddie

2002 Modeled Paleoenvironmental and ArchaeoResource Frames of Reference for the Southwestern Green River Basin. In Data Recovery Excavations at Site 48SW375, Uinta County, Wyoming, by Thomas P. Reust, Russell Richard, William E. Eckerle, Sasha Taddie, Craig S. Smith, and Darryl W. Newton, pp. 171-196. Report commissioned by TRC Mariah Associates, Laramie, Wyoming.

Eerkens, Jelmer W., and Jeffrey S. Rosenthal

2002 Transition from Geophyte to Seed Processing: Evidence for Intensification from Thermal Features near China Lake, Northern Mojave Desert. Pacific Coast Archaeological Society Quarterly 38(2-3):19-36.

Fewkes, J. Walter

1896 A Contribution to Ethnobotany. American Anthropologist 9:14-21.

Fulkerson, Tiffany J., and Shannon Tushingham

2021 Geophyte Field Processing, Storage, and Women's Decision-Making in Hunter-Gatherer Societies: An Archaeological Case Study from Western North America. Journal of Anthropological Archaeology 62:101299.

Gao, Ming, Mahta Moussavi, and Deland Myers

2021 Analysis and Specification of Starch Granule Size Distributions. Journal of Visualized Experiments. DOI:10.3791/61586.

Gill, Kristina M

2016 10,000 Years of Geophyte Use among the Island Chumash of the Northern Channel Islands. Fremontia 44(3):34-38.

Gill, Kristina M., Todd J. Braje, Kevin Smith, and Jon M. Erlandson

2021 Earliest Evidence of Geophyte Use in North America: 11,500-Year-Old Archaeobotanical Remains from California's Santarosae Island. American Antiquity 86:625-637.

Gremillion, Kristen J.

2004 Seed Processing and the Origins of Food Production in Eastern North America. American Antiquity 69:215-233.

Herzog, Nicole M.

2014 Starch Granule Analysis in California and the Great Basin. California Archaeology 6:171-189.

Herzog, Nicole M., and Anne T. Lawlor

2016 Reevaluating Diet and Technology in the Archaic Great Basin Using Starch Grain Assemblages from Hogup Cave, Utah. American Antiquity 81:664-681.

Holst, Irene., J. Enrique. Moreno, and Dolores R. Piperno

2007 Identification of Teosinte, Maize, and Tripsacum in Mesoamerica by Using Pollen, Starch Grains, and Phytoliths. PNAS 104:17608-17613.

International Code for Starch Nomenclature (ICSN)

2011 The International Code for Starch Nomenclature. Electronic document, http://fossilfarm.org/ICSN/Code. html, accessed June 2020.

Kelly, Isabel T.

1932 Ethnography of the Surprise Valley Paiute. University of California Publications in American Archaeology and Ethnology. University of California Press, Berkeley.

1934 Southern Paiute Bands. American Anthropologist 36:548-560.
Kelly, Robert L.

1995 The Foraging Spectrum: Diversity in Hunter-Gatherer Lifeways. Smithsonian Institution, Washington DC.

Larson, Mary Lou

1997 Housepits and Mobile Hunter-Gatherers: A Consideration of the Wyoming Evidence. Plains Anthropologist 42:353-369.

Lawton, Harry W., Philip J. Wilke, Mary DeDecker, and William M. Mason

1976 Agriculture among the Paiute of Owens Valley. Journal of California Anthropology 3(1):13-50.

Lepofsky, Dana, and Sandra L. Peacock

2004 A Question of Intensity: Exploring the Role of Plant Foods in Northern Plateau Prehistory. In Complex Hunter Gatherers: Evolution and Organization of Prehistoric Communities on the Plateau of Northwestern North America, edited by William C. Prentis, pp. 3648. University of Utah Press, Salt Lake City.

Lewis, Meriwether, William Clark, and Nicholas Biddle

1814 History of the Expedition under the Command of Captains Lewis and Clark, to the Sources of the Missouri, Thence across the Rocky Mountains and down the River Columbia to the Pacific Ocean: Performed during the Years 1804-5-6. By Order of the Government of the United States. Vol. 1. Bradford and Inskeep, Philadelphia.

Liu, L., Sai Ma, and Jianxin Cui

2014 Identification of Starch Granules Using a Two-Step Identification Method. Journal of Archaeological Science 52:421-427.

Louderback, Lisbeth A., Nicole M. Herzog, and Bruce M. Pavlik

2017 A New Approach for Identifying Starch Granules of Wild Food Plants from Arid Western North America Starch - Stärke 69(5-6). DOI:10.1002/star.201600167.

Louderback, Lisbeth A., and Bruce M. Pavlik

2017 Starch Granule Evidence for the Earliest Potato Use in North America. PNAS 114:7606-7610.

Lyons, Natasha, and Morgan Ritchie

2017 The Archaeology of Camas Production and Exchange on the Northwest Coast: With Evidence from a Sts'ailes (Chehalis) Village on the Harrison River, British Columbia. Journal of Ethnobiology 37:346-367.

McGuire, Kelly, and Nathan Stevens

2016 The Archaeological Correlates and Evolution of Geophyte Procurement in the Northwestern Great Basin. In Prehistory of Nevada's Northern Tier: Archaeological Investigations along the Ruby Pipeline, edited by William Hildebrandt, Kelly McGuire, Jerome King, Allika Ruby, and D. Craig Young pp. 279-302. Anthropological Papers No. 101. American Museum of Natural History, New York.

Musaubach, María Gabriela, Anabela Plos, and María Del Pilar Babot

2013 Differentiation of Archaeological Maize (Zea mays L.) from Native Wild Grasses Based on Starch Grain Morphology: Cases from the Central Pampas of Argentina. Journal of Archaeological Science 40:1186-1193.

O'Connell, James F., Kristen Hawkes, and Nick G. Blurton Jones

1999 Grandmothering and the Evolution of Homo erectus. Journal of Human Evolution 36:461-485.

Perry, Linda, and J. Michael Quigg

2011 Starch Remains and Stone Boiling in the Texas Panhandle Part II: Identifying Wildrye (Elymus spp.). Plains Anthropologist 56:109-119. 
Pool, Kelly J.

2001 Colorado Interstate Gas Company Uinta Basin Lateral: Final Report of Excavations, Moffat and Rio Blanco Counties, Colorado and Sweetwater County, Wyoming. Volume 29: 48SW8842. Metcalf Archaeological Consultants, Eagle, Colorado.

Rankin, Amanda M.

2016 Starch Residue Analysis from Two High Altitude Village Locations: High Rise Village, Wyoming and the White Mountain Village Sites, California. Master's thesis, Department of Anthropology, University of Nevada, Reno.

$\mathrm{R}$ Core Team

2019 R: A Language and Environment for Statistical Computing. R Foundation for Statistical Computing, Vienna, Austria. Electronic document, https://www. gbif.org/tool/81287/r-a-language-and-environment-forstatistical-computing, June 2020

Reichert, Edward Tyson

1913 The Differentiation and Specificity of Starches in Relation to Genera, Species, etc.; Stereochemistry Applied to Protoplasmic Processes and Products, and as a Strictly Scientific Basis for the Classification of Plants and Animals. Carnegie Institution of Washington, Washington, DC.

Reimer, Paula J., Edouard Bard, Alex Bayliss, J. Warren Beck, Paul G. Blackwell, Christopher Bronk Ramsey, Caitlin E. Buck, et al.

2013 IntCal13 and Marine13 Radiocarbon Age Calibration Curves 0-50,000 Years cal BP. Radiocarbon 55:1869-1887.

Reust, Thomas P., Russell Richard, William P. Eckerle, Sasha Taddie, Craig S. Smith, and Darryl W. Newton

2002 Data Recovery Excavations at Site 48UT375, Uinta County, Wyoming. TRC Mariah Associates, Laramie, Wyoming.

Rhode, David, and Amanda M. Rankin

2020 Plant Macrofossils from Alta Toquima and Starch Remains from Alta Toquima and Gatecliff Shelter. In Alpine Archaeology of Alta Toquima and the Mt. Jefferson Tablelands (Nevada), edited by David Hurst Thomas, pp. 353-372. Anthropological Papers No. 104. American Museum of Natural History, New York.

Rhode, David, and Allise A. Rhode

2015 Energetic Return Rates from Limber Pine Seeds. Journal of California and Great Basin Anthropology 35:291-304.

Robinson, Erick, H., Jabran Zahid, Brian F. Codding, Randall Haas, Robert L. Kelly

2019 Spatiotemporal Dynamics of Prehistoric Human Population Growth: Radiocarbon "Dates as Data" and Population Ecology Models. Journal of Archaeological Science 101:63-71.

Simms, Steven R.

1987 Behavioral Ecology and Hunter-Gatherer Foraging: An Example from the Great Basin. BAR International Series 381. British Archaeological Reports, Oxford.

Smith, Craig S.

2003 Hunter-Gatherer Mobility, Storage, and Houses in a Marginal Environment: An Example from the MidHolocene of Wyoming. Journal of Anthropological Archaeology 22:162-189.

Smith, Craig S., William Martin, and Kristine A. Johansen

2001 Sego Lilies and Prehistoric Foragers: Return Rates, Pit Ovens, and Carbohydrates. Journal of Archaeological Science 28:169-183.
Smith, Craig S., and Lance M. McNees

2005 Cymopterus bulbosus and Prehistoric Foragers: Patch Size, Plant Density, and Return Rates. Journal of Ethnobiology 25:1-23.

2011 Persistent Land Use Patterns and the Mid-Holocene Housepits of Wyoming. Journal of Field Archaeology 36:298-311.

Smith, Craig S., Thomas P. Reust, and Russell D. Richard

2003 Site 48UT375: Late Paleoindian Period Subsistence and Land Use Patterns in the Green River Basin, Wyoming. Plains Anthropologist 48:133-149.

Steward, Julian H.

1933 Ethnography of the Owens Valley Paiute. University of California Publications in American Archaeology and Ethnology 33. University of California Press, Berkeley.

Sutton, Elizabeth A.

2014 Digging Stick Weights and Doughnut Stones: An Analysis of Perforated Stones from the Santa Barbara Channel Region. Journal of California and Great Basin Anthropology 34:17-42.

Swank, George R.

1932 The Ethnobotany of the Acoma and Laguna Indians. Master's thesis, Department of Anthropology, University of New Mexico, Albuquerque.

Thoms, Alston V.

1989 The Northern Roots of Hunter-Gatherer Intensification: Camas and the Pacific Northwest. PhD dissertation, Department of Anthropology, Washington State University, Pullman.

Thoms, Alston V., Laura M. Short, Masahiro Kamiya, and Andrew R. Laurence

2018 Ethnographies and Actualistic Cooking Experiments: Ethnoarchaeological Pathways toward Understanding Earth-Oven Variability in Archaeological Records. Ethnoarchaeology 10:76-98.

Ugan, Andrew, and Jeffrey Rosenthal

2016 Brodiaea Return Rates and Their Ethnographic and Archaeological Implications for Occupations of the Northwestern Mojave Desert of North America. Journal of California and Great Basin Anthropology 36:73-90.

Vestal, Paul A.

1940 Notes on a Collection of Plants from the Hopi Indian Region of Arizona Made by J. G. Owens in 1891. Botanical Museum Leaflets (Harvard University) 8(8):153-168.

1952 The Ethnobotany of the Ramah Navaho. Papers of the Peabody Museum of American Archaeology and Ethnology 40. Harvard University, Cambridge, Massachusetts.

Wilks, Stefania, Lisbeth A. Louderback, and Shannon Boomgarden

2021 Starch Granule Size and Morphology as a Proxy for Water Regime Influence on Zea mays. Ethnobiology Letters 12:35-43.

Zahid, H. Jabran., Robinson, Erick R., Kelly, Robert L.

2016 Agriculture, Population Growth, and Statistical Analysis of the Radiocarbon Record. PNAS 113: 931-935.

Zeanah, David W

2004 Sexual Division of Labor and Central Place Foraging: A Model for the Carson Desert of Western Nevada. Journal of Anthropological Archaeology 23:1-32.

Submitted February 12, 2021; Revised June 11, 2021; Accepted June 24, 2021 